\title{
Development of Cutter Head Design in Cutter Suction Dredger with Thickness and Pitch Variation
}

\begin{abstract}
Amiadji ${ }^{1}$, Achmad Baidowi ${ }^{2}$, Riyan Prayogo ${ }^{3}$
Received: 31 January 2019 / Revised: 18 March 2019 / Accepted: 19 March 2019

Abstract - the need for dredgers for the shallow water in the sea with a very high level of siltation on the coast of Indonesia is a factor worth considering. For example, coastal areas in Ujung Pangkah sub-district, Gresik district, East Java province. The choice of the area is due to the many institutions and corporations that are back and forth utilizing these waterways. But the main obstacle to making a Cutter Suction Dredger (CSD) is almost all the equipment needed is imported, for example, the main equipment is the cutter head. Therefore looking at the needs, economics and technology factors, this paper will discuss the cutter head design. Available data is a request from the owner, $40 \mathrm{KW}$ power cutter head; $1000 \mathrm{~mm}$ cutter diameter; 30rpm rotation. The force distribution given $5950 \mathrm{~N}$ is in accordance with the dredging condition which is to have a strong material tension to be estimated to work at a relatively Soft density of $<100$ Mpa and Medium around 100Mpa - 170Mpa. The expected results of this design are to obtain a proportional design before the production process and to function at a minimum according to specifications. The usefulness of this design really hopes to be followed up to the production stage and can be applied.
\end{abstract}

Keywords-CATIA, Cutter Suction Dredger (CSD), Cutter Head.

\section{INTRODUCTION}

$\mathrm{U}$ jung Pangkah is one of the coastal areas in Gresik Regency, East Java which has experienced a lot of sedimentation due to sediment carried by the Bengawan
Solo river. The results showed that the coastline in Ujung Pangkah experienced many changes due to accretion and abrasion. The accretion area reached $11.35 \mathrm{~km}^{2}$ and abrasion was $5.19 \mathrm{~km}$ in a period of 15 years [1]. One example of a sedimentation contributor is the Bengawan Solo river where the estuary of the longest river in Java carries material with deposits reaching $2.79 \mathrm{~kg} / \mathrm{m}^{3}$ [2].

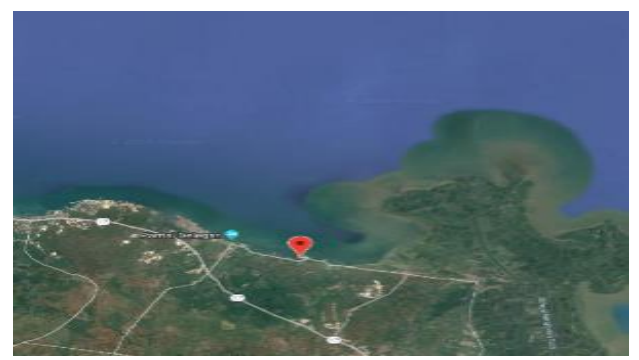

Figure 1. Maps sub-distric. ujung pangkah.

The dredging flow is determined by the condition of the land which can be in the form of mud, sand, sandy mud or rock, generally coastal lands in Indonesia in the form of mud or sandy mud [3]. From the study above, the biggest obstacle is in shallow sea conditions.

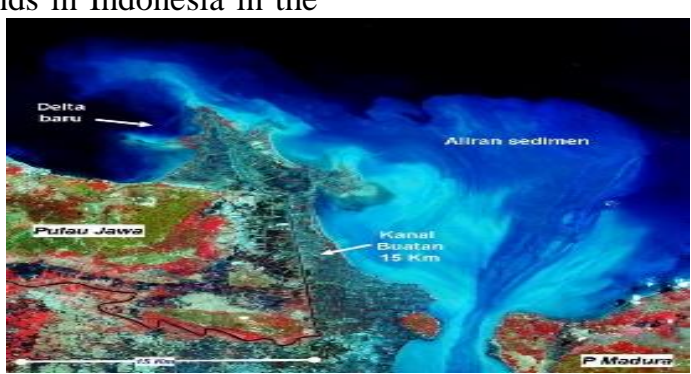

Figure 2. Sediment flow

${ }^{1}$ Amiadji, Department of Marine Engineering, Institut Teknologi Sepuluh Nopember, Surabaya 60111, Indonesia, Email: amiadji@its.ac.id

${ }^{2}$ Achmad Baidowi, Department of Marine Engineering, Institut Teknologi Sepuluh Nopember, Surabaya 60111, Indonesia, Email: ahmadbai@gmail.com ${ }^{3}$ Riyan Prayogo, Department of Marine Engineering, Institut Teknologi Sepuluh Nopember, Surabaya 60111, Indonesia, Email: yanyogo@gmail.com
A dredger is a piece of equipment that can dig, carry, disposed with a certain amount of soil below water level at a certain time. For example, water is flowed using a dredge pump through a suction pipe. The type of dredger to be used is the cutter suction dredger. To solve the 
problem, we must complete the design one by one and make sure that it can work accordingly by carrying out design simulations. We provide screenshots to visualize and make it easy to understand below.

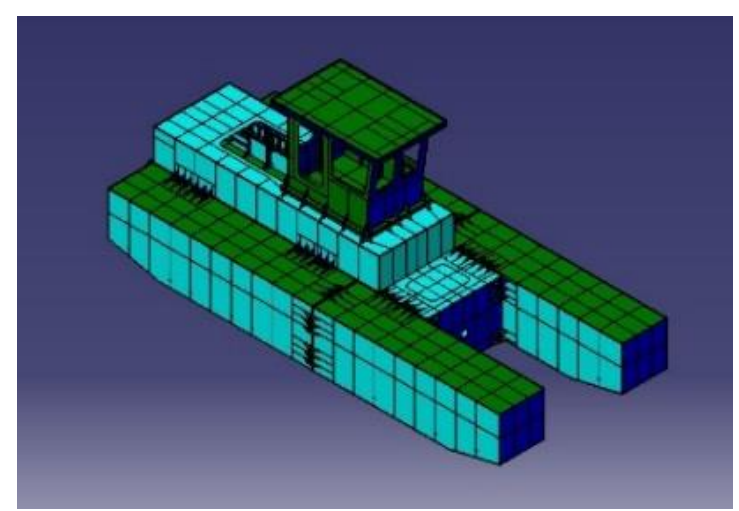

Figure 3. 3D construction from cutter suction dredger.

\section{METHOD}

\section{A. Cutter Suction Dredger}

Cutter Suction Dredger (CSD) is a digging tool of soils that are moved using a rotating cutter head that is driven hydraulically or mechanically. The mud pump inside the ship is primarily used to suck material and move to the surface and remove both into the barge or other according to plan. There are 2 main types for CSD, which do not have a propeller made similar to a barge or pontoon or have their own propeller (self-propelled) [4]. There are two types of cutter head motion, that are overcutting and undercutting [5]. The ability of the cutter teeth is planned to operate within $8 \mathrm{~m}$ depth with the prediction of the soil density at a relatively soft of $<100$ Mpa and Medium around $100 \mathrm{Mpa}-170 \mathrm{Mpa}$. To ensure the toughness of cutter teeth, wear out durability should be higher than abrasive durability, which the value is 3 to 4 times that of conventional steel equipment [6]. There are several types of dredgers that can be seen in Figure 4.

\section{B. Type of Soil}

The types of soil and rock material found near the coast refer to the geology of Keeper Reef by showing the condition of a cross-section along $720 \mathrm{~m}$ with depths up to $22 \mathrm{~m}$ [7].

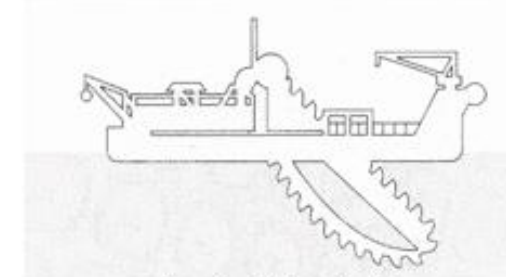

Bucket ladder dredge

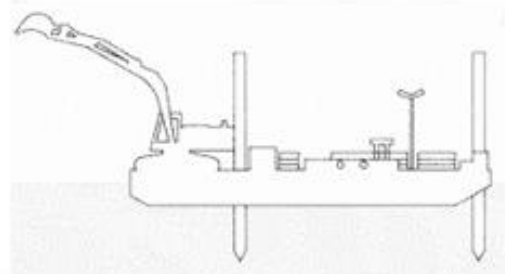

Dipper and backhoe dredge

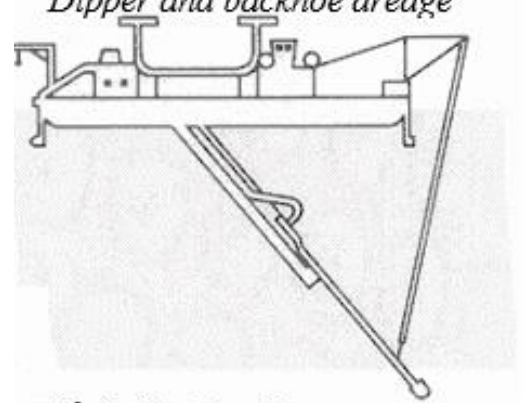

Plain Suction Dregger

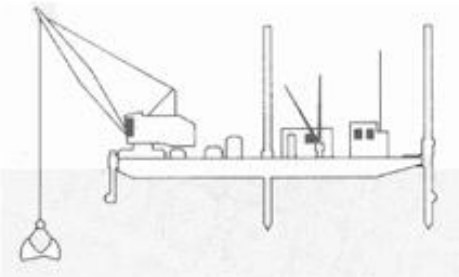

Grab dredge

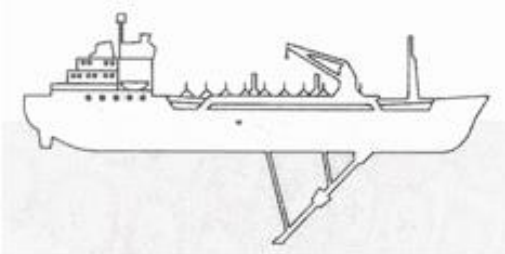

Trailing suction hopper dredge

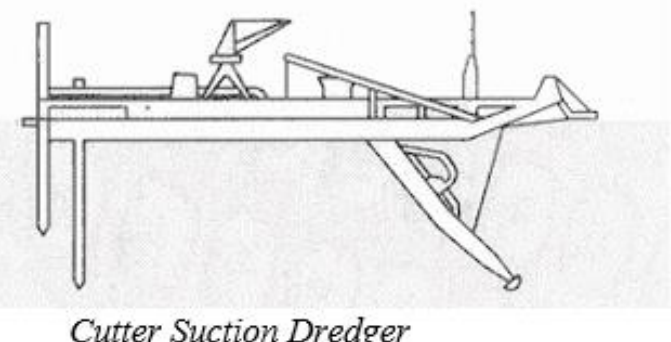

Cutter Suction Dredger

Figure 4. Kind of Cutter Suction Dredger 


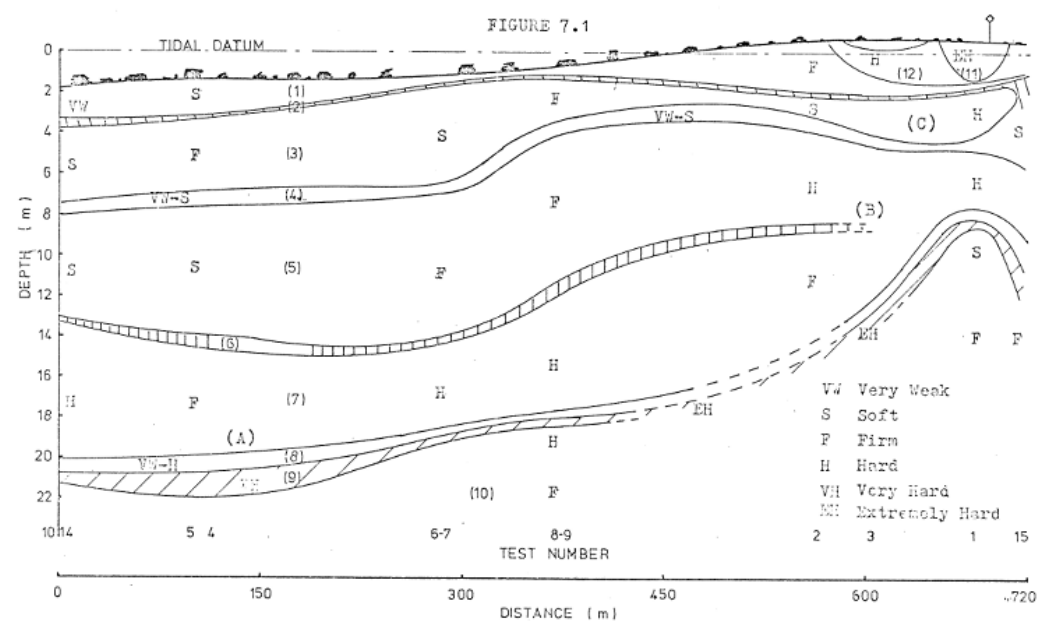

Figure 5. The composition of the soil material to a depth of 20m [7].

Specific classification above can be used as a basis for consideration of material that used for dredging. The CSD designed in this study has a depth of up to $8 \mathrm{~m}$. By referring to the cross-section of the formation of soil material layers, it can be predicted that the material to be dredging is to have a relative density (S) Soft and (F) Firm. For the types of material that might appear in the area can be seen in the table.

TABLE 1.

GENERAL INDICATION OF CUTTER TYPE SELECTION [8]

\begin{tabular}{|c|c|c|c|}
\hline Relative Density & Material Strength & Possible Material & Cutter Selection \\
\hline Soft & 0-100 Мpa & $\begin{array}{l}\text { (S) - Salt } \\
\text { (S) - Coarse-grained, weakly cemented sandstones } \\
\text { (S) - Fossiliferous limestones } \\
\text { (I) - Altered igneous rocks } \\
\text { (S) - Claystones, shales } \\
\text { (S) - Coal }\end{array}$ & $\begin{array}{l}\text { Partial } \\
\text { Face } \\
\text { Pick }\end{array}$ \\
\hline Medium & $100-170 \mathrm{Mpa}$ & $\begin{array}{l}\text { (S) - Marlstones, Limestones } \\
\text { (M) - Marble } \\
\text { (S) - Shales, siltstones, sandstones } \\
\text { (M) - Phyllites } \\
\text { (M) - Highly micaceous schists } \\
\text { (M) - Altered intrusive igneous rocks } \\
\text { (M) - Altered metamorphic rocks }\end{array}$ & $\begin{array}{c}\text { Heavy } \\
\text { Partial } \\
\text { Face } \\
\text { Pick } \\
\text { Marginal } \\
\text { Full Face Disc }\end{array}$ \\
\hline Hard & $170-240 \mathrm{Mpa}$ & $\begin{array}{l}\text { (M) - Slates } \\
\text { (S) - Crystalline limestone } \\
\text { (I) - Diabase } \\
\text { (S) - Silicious, cemented sandstones } \\
\text { (M) - Gneisses and schists } \\
\text { (I) - Pyroxenites } \\
\text { (I) - Coarse-grained granites }\end{array}$ & $\begin{array}{c}\text { Full face discs } \\
\text { Marginal } \\
\text { Full face carbide button cutters }\end{array}$ \\
\hline Very Hard & $240 \mathrm{Mpa}$ & $\begin{array}{l}\text { (M) - Quartzites } \\
\text { (M) - Amphibolites } \\
\text { (S) - Dolomites } \\
\text { (I) - Fine-grained granites } \\
\text { (I) - Basalt, diabase } \\
\text { (I) - Syenites } \\
\text { (I) - Gabbros }\end{array}$ & Blasting \\
\hline
\end{tabular}

\section{Rock classes:}

(S) Sedimentary

(I) Igneous Rocks

(M) Metamorphic

Note: current on-going research suggests both thresholds of pick and discs could be increased significantly with the use of high-pressure water jet assisted cutting. 
The ability of the Cutter's teeth is planned to operate within $8 \mathrm{~m}$ with the prediction of working soil material at a relatively Soft density of $<100 \mathrm{Mpa}$ and for Medium around $100 \mathrm{Mpa}-170 \mathrm{Mpa}$. To ensure the toughness of cutter teeth, wear resistance must be higher than abrasive resistance where the value is 3 to 4 times that of conventional steel equipment [6]. The hardness of the cutter material standard must be 40 HRC (Rockwell C Hardness) or $373 \mathrm{HB}$ (Brinell Hardness) or $388 \mathrm{HV}$ (Vickers Hardness) or minimum cutter material voltage of $1265 \mathrm{~N} / \mathrm{mm}^{2}$ [9]. The type of cutter teeth material to be used is the S2 series Stell Alloy which has a hardness value of 440-520 $\mathrm{HB}$ and a yield of $1500 \mathrm{~N} / \mathrm{mm}^{2}$. The $\mathrm{S}$ series type is intended for shock resisting [10], other suitable alloy materials can be seen in ASTM-A681.

\section{Stress Analysis}

Stress Analysis is a science of engineering that uses methods to determine the stresses and strains of materials and structures that are subjected to force. In mechanics, the definition of stress is a physical quality that shows the strength of internal particle bonds.

To speed up the analysis process and maintain the accuracy of 3D results and stress analysis multi-platform commercial CAD / CAM / CAE developed by the French company "Dassault Systemes" and marketed worldwide by IBM, and written in $\mathrm{C}++$ programming language, and CATIA is the foundation of the Dassault Systemes Product Lifecycle Management software suite. This software is not only used to conFigure 2D and 3D because this multi-platform CAD / CAM / CAE software can also be used for planning and designing the machining process of a product, making simulations, and analyzing the characteristics of the product. The difference in manual calculations and computational calculations by use CATIA software should be less than $7 \%$ [11].

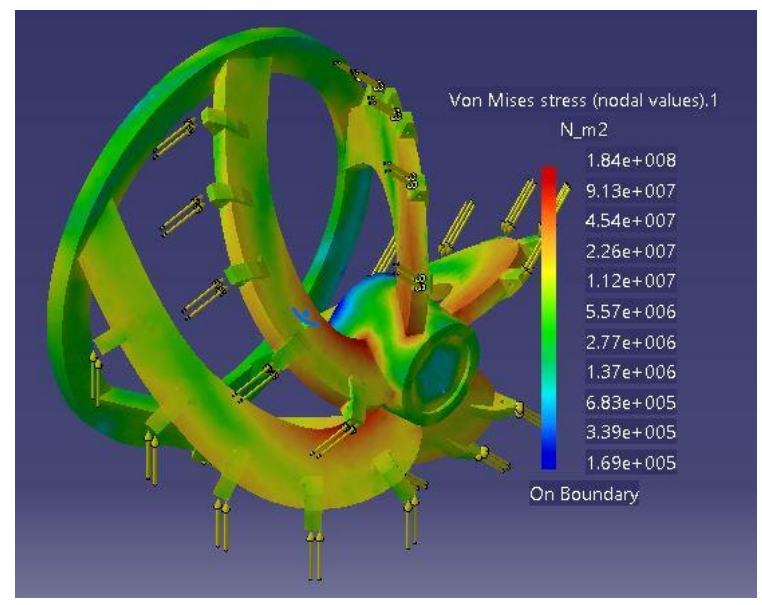

Figure 6. CATIA stress analysis.

D. The effect of Stress Analysis on Head Cutter

Many parameters influence, from the most basic things, namely the type or classification of soil material that will be processed dredging and knowing the strength of the material strain into consideration before entering the design process.

For the second parameter, the ability of the dredging tool itself. If it is described in a complex manner, there are certainly many factors that affect it, but as a limitation, dimension parameters of the cutter blade to be used in this analysis. The material that has been used in this analysis is the type of mild steel grade A material for marine use, and for the dimension parameter, the parameters for the change in angle and thickness that has been varied to be more clear in Figure 6 .

To facilitate classification based parameter above then our working condition (WC) present in Table 2. Each WC has been subjected to a stress analysis with the following output targets: 


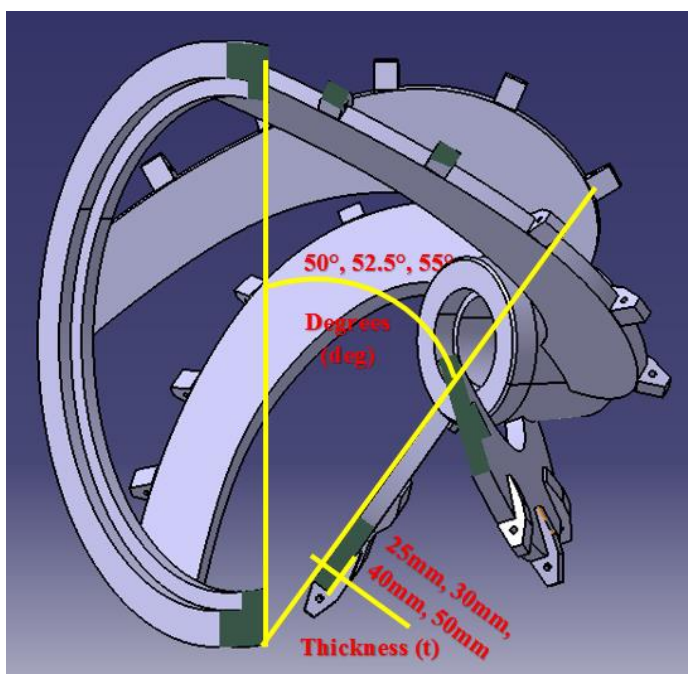

Figure 7. Parameters change in angle and thickness.

TABLE 2.

ClassificATION WORKING CONDITION (WC).

\begin{tabular}{cccc}
\hline $\begin{array}{c}\text { Degree } \\
\text { Thickness }\end{array}$ & $\mathbf{5 0}^{\circ}$ & $\mathbf{5 2 . 5}^{\circ}$ & $\mathbf{5 5}^{\circ}$ \\
\hline $25 \mathrm{~mm}$ & WC1A & WC1B & WC1C \\
$35 \mathrm{~mm}$ & WC2A & WC2B & WC3C \\
$40 \mathrm{~mm}$ & WC3A & WC3B & WC3C \\
$50 \mathrm{~mm}$ & WC4A & WC4B & WC4C \\
\hline
\end{tabular}

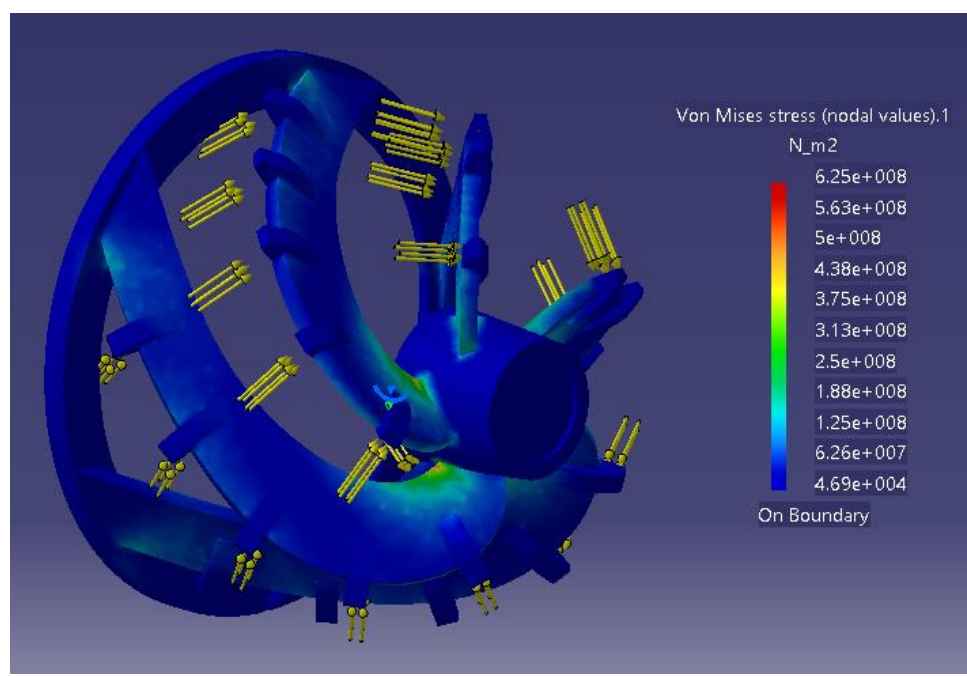

Figure 8. An example of the results of Von Mises Stress is stress analysis.

E. Determination of Dimensions and Parameters

Data available at the request of the owner has the following specifications: $40 \mathrm{KW}$ power cutter head;
$1000 \mathrm{~mm}$ cutter diameter; 30rpm rotation. The schematic diagram of the cutter head design is as follows: 


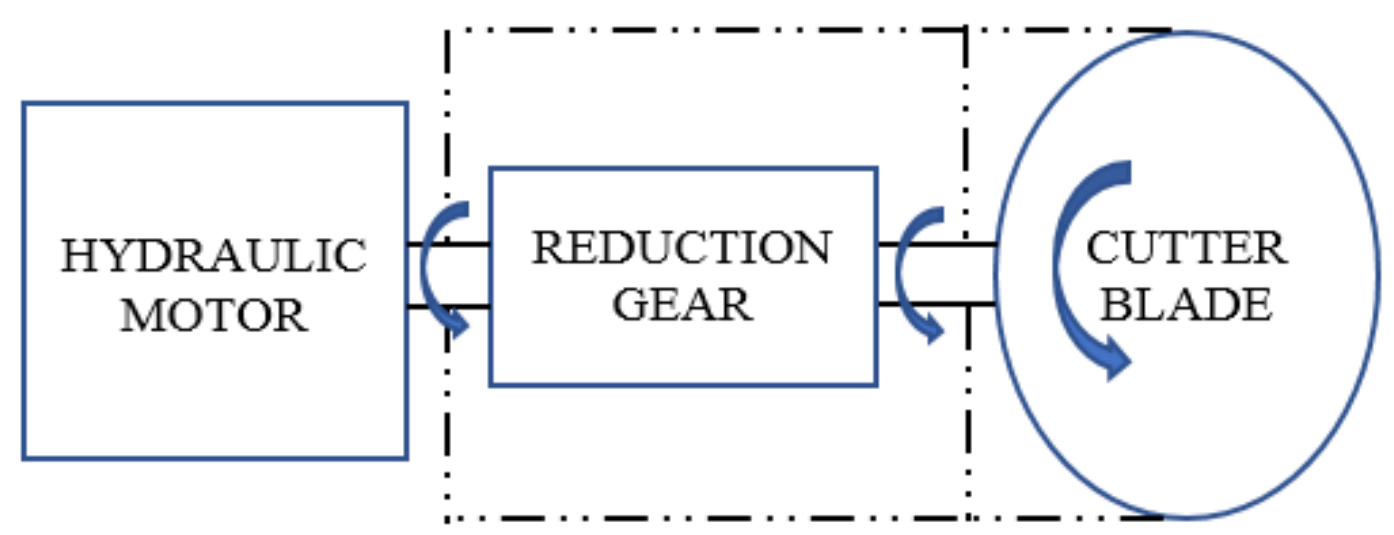

Figure 9. Cutter head planning diagram scheme.

\section{F. Basic theory}

When the material is given it will produce bending stress. Bending stress is a type of normal stress but a little more specific.

In general, to get bending stress can use the formula below:

$$
\sigma_{\mathrm{b}}=\frac{\mathrm{M}_{\mathrm{b}}}{\mathrm{Sx}}
$$

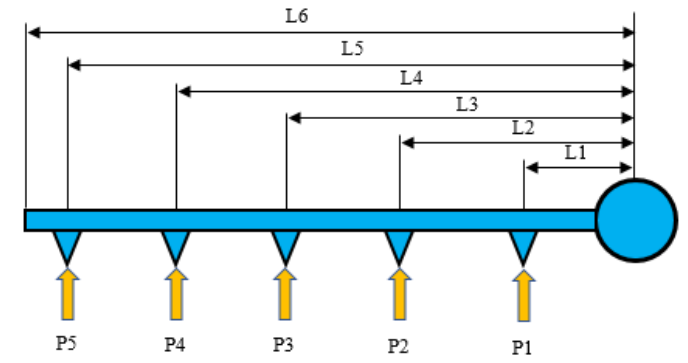

Figure 10. Radial cutter blade style

Where :

$$
\begin{array}{ll}
\mathrm{P} & =\text { Force }(\mathrm{N}) \\
\mathrm{L} & =\text { Length from the center }(\mathrm{mm}) \\
\Sigma \mathrm{Mb} & =\text { Total of moment }(\mathrm{N} \cdot \mathrm{mm})
\end{array}
$$

So :

$$
\Sigma \mathrm{Mb}=(\mathrm{L} 1 \cdot \mathrm{P} 1)+(\mathrm{L} 2 \cdot \mathrm{P} 2)+(\mathrm{L} 3 \cdot \mathrm{P} 3)+(\mathrm{L} 4 \cdot \mathrm{P} 4)+
$$

Because the force required at each point is not known, the force required for the soil dredging process can use the following equation [12]:
Where:

$\sigma \mathrm{b} \quad=$ Bending Stress $\left(\mathrm{N} / \mathrm{mm}^{2}\right)$

$\mathrm{Mb}=$ Bending moment $(\mathrm{N} \cdot \mathrm{mm})$

$\mathrm{Sx} \quad=$ Plastic Section Modulus $\left(\mathrm{mm}^{3}\right)$

Basically, to match the radial force given to the blade cutter then the force direction is like Figure 9. 
So that in general the plastic section modulus can be determined as follows:

$$
\mathrm{Sx}=\frac{\mathrm{a}^{2} \cdot \mathrm{b}}{4}
$$

Where :

$\mathrm{Sx}=$ Plastic section modulus $\left(\mathrm{mm}^{3}\right)$
Power determination uses the following equation:

$$
\mathrm{P}=\mathrm{T} \cdot \omega
$$

Where :

$\mathrm{P} \quad=$ Power $(\mathrm{kW})$

$\mathrm{T}=$ Torque $(\mathrm{Nm})$

$\omega \quad=$ Angulat speed $(\mathrm{rad} / \mathrm{s})$

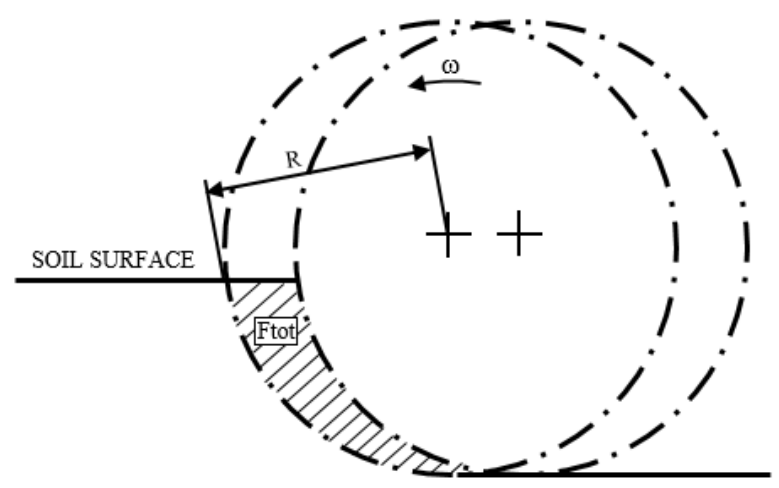

Figure 12. Distribution in circle segments.

From the Figure above, then:

For equations look for torque in general as follows [13]:

$$
\mathrm{T}=\mathrm{R} \cdot \mathrm{F}_{\text {tot }}
$$

While for the equation looking for angular speed in general as follows:

$$
\omega=\frac{(2 \cdot \pi \cdot n)}{60}
$$

So, the equation looks for the rotational power of the rotor to be:

$$
\mathbf{P}=\mathbf{R} \cdot \mathbf{F}_{\text {tot }} \cdot \frac{(2 \cdot \pi \cdot \mathbf{n})}{60}
$$

\section{RESULT AND DISCUSSION}

A. Modeling of the cutter Head and Blade Cutter
Cutter head and blade cutter will be used in this research as the main object. It will be observed and analyze which one from this object will generate great results.

\section{A. 3D Modeling and 2D Drawing}

The main part of the cutter blade itself is there is a knife for the dredging gear, the hub for the shaft house, and the ring for reinforcement on the outside. Design parameters of the blade for the cutting gear spot; design of a hub shape; the material used; and the main parameters raised in this study are according to the results of previous calculations and planning. For the results of geometry modeling using CAD software and for 3D modeling using CATIA V5 software can be seen in the Figure below. 


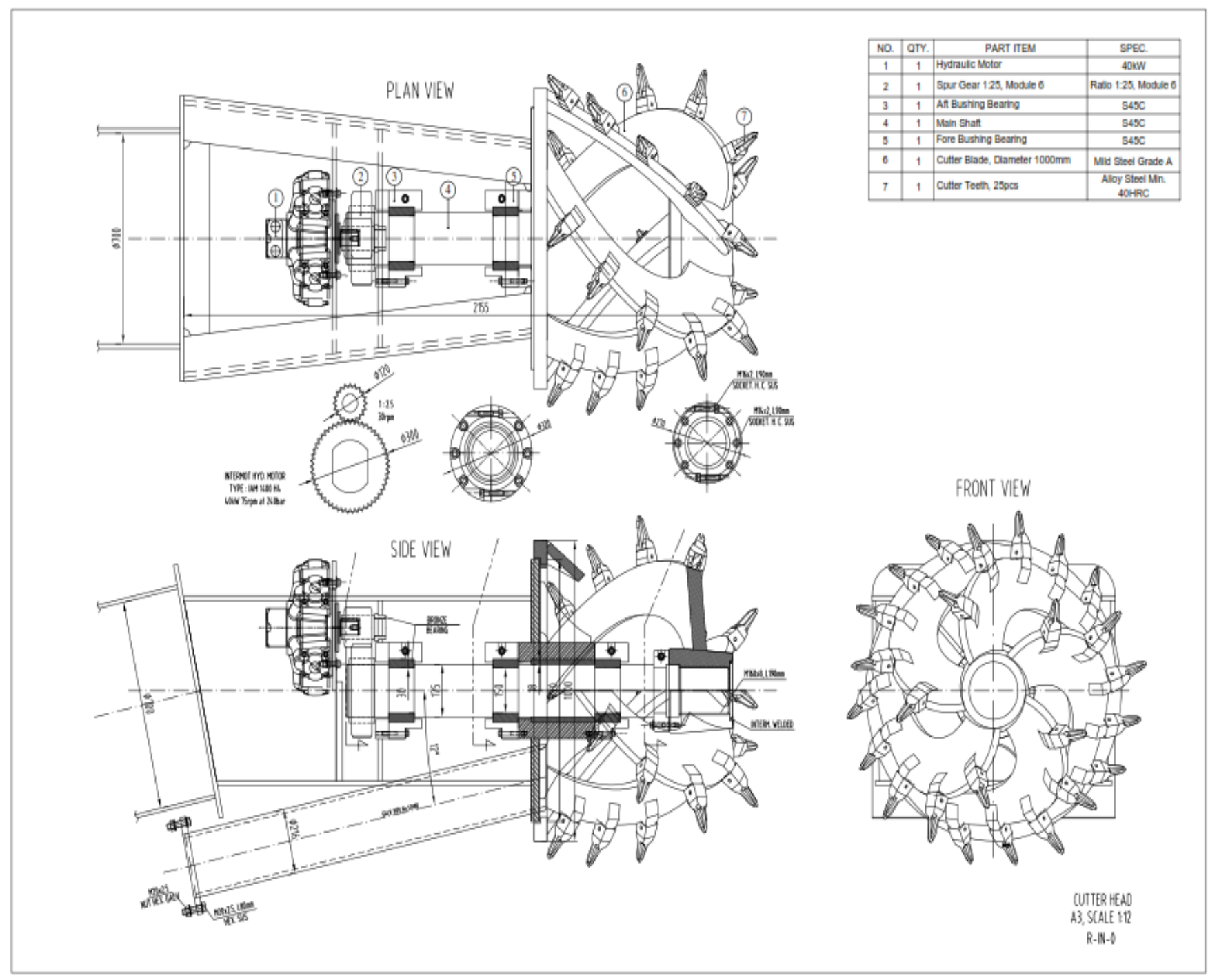

Figure 13. 2D drawing of Head Cutter.
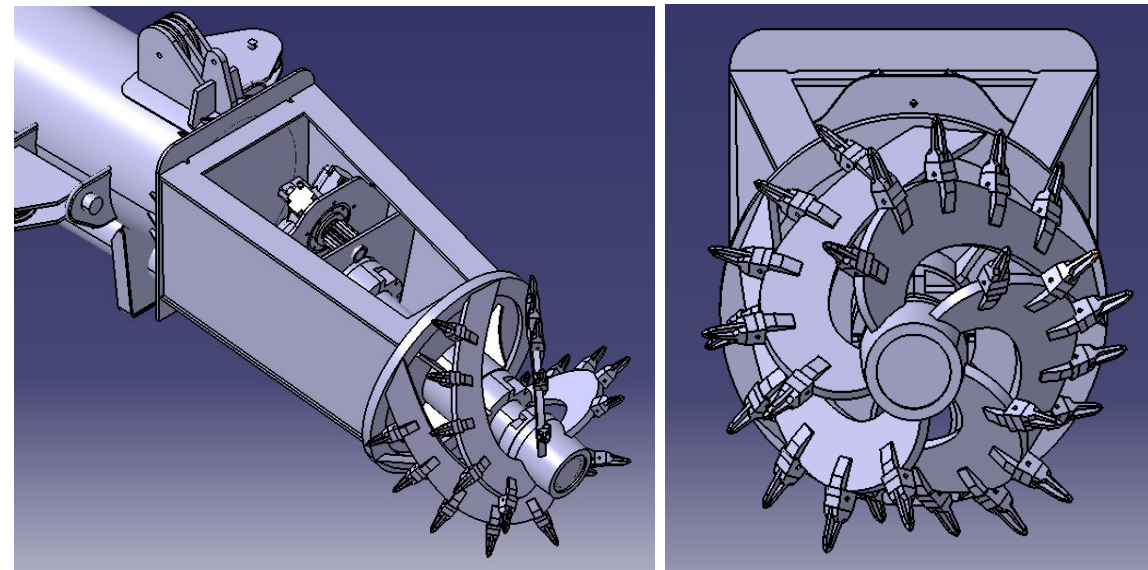

Figure 14. 3D Model drawing of Cutter Head. 


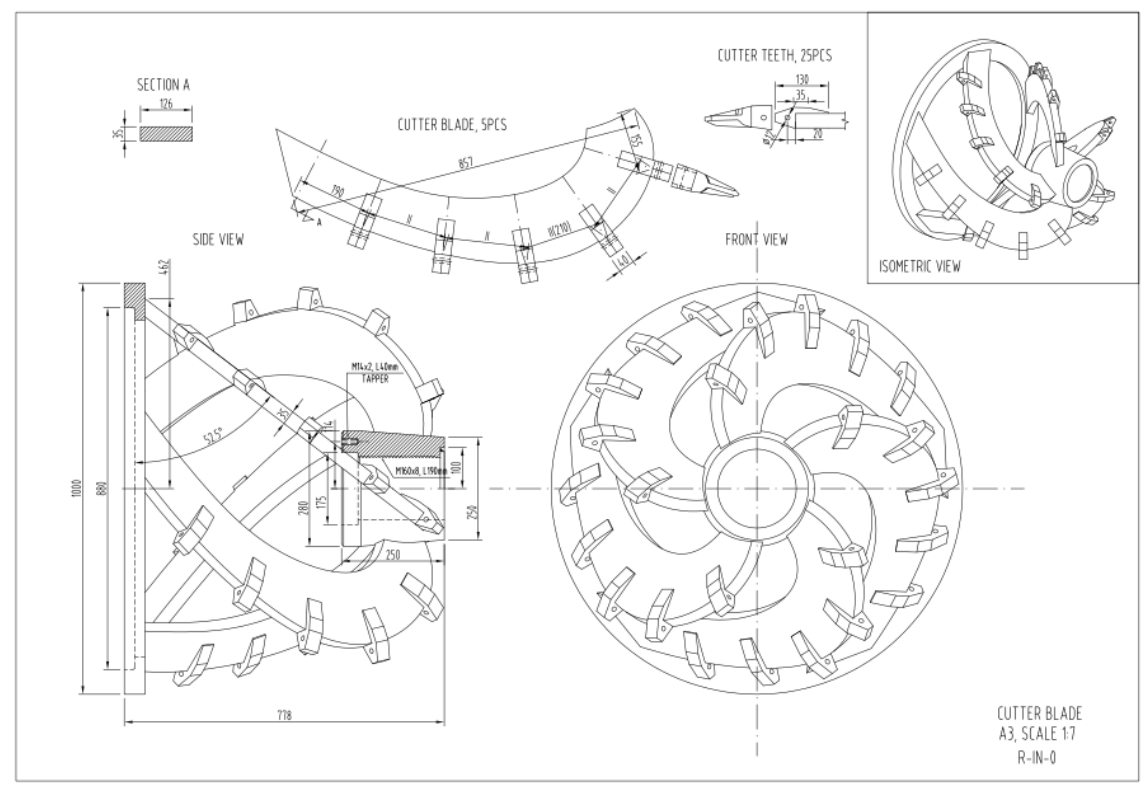

Figure 15. 2D of Cutter Blade.

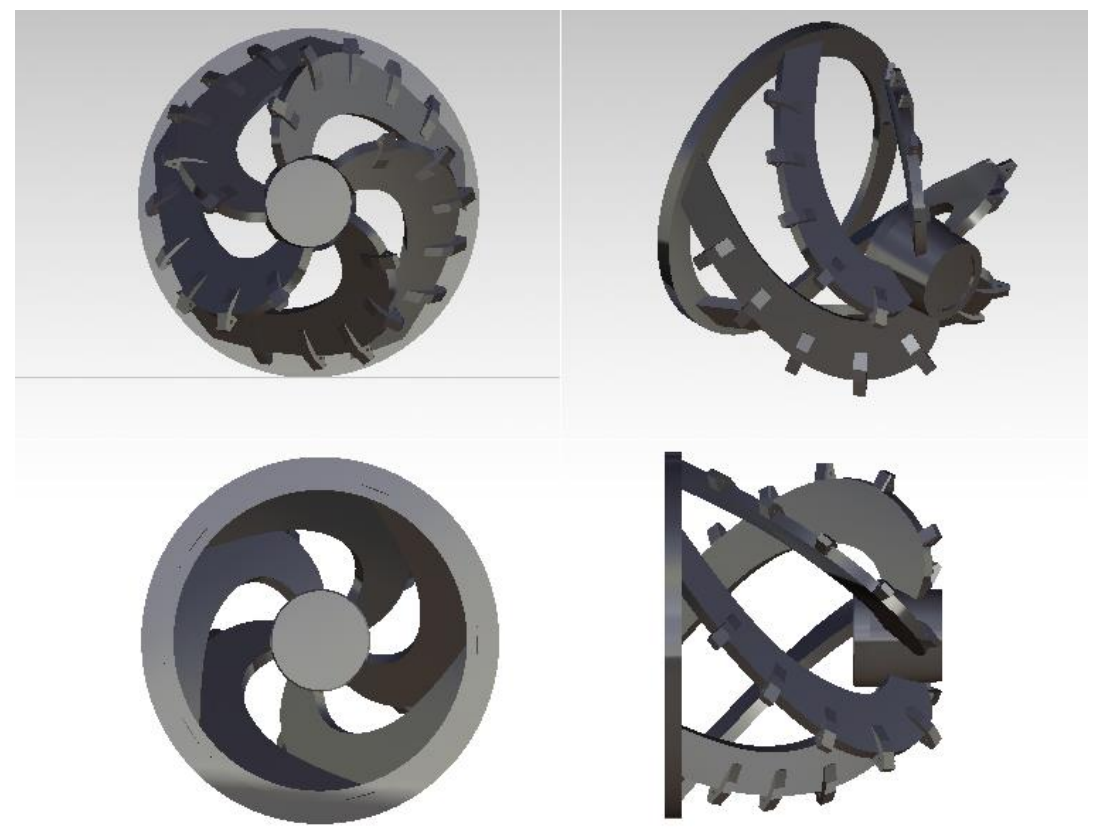

Figure 16. 3D Model drawing of Cutter Blade.

B. Convergence of Mesh Refinement

Finite Element Method (FEM) can be described as a numerical simulation method that is used to estimate the response/behavior of a component/system under certain conditions, by dividing the component/system in question into smaller (discretized) parts called element, with a certain number (finite). In the literature on finite element methods (FEM), it is often mentioned that the accuracy of the finite element solution increases with the increasing number of elements used, but with the increasing number of elements used, the time needed for computing is also greater. Even sometimes the number of elements that are too large will increase the round-off error.
In the application, one of the recommendations for determining the number of elements with the accuracy of an acceptable solution in a finite element analysis is to conduct a convergence test (convergence test) on the solution obtained. The example is the stress analysis on a component, the initial analysis is carried out with the size/number of certain elements, the solution is obtained by completing the model used. The analysis is then repeated with a larger number of elements, the value of the stress at a particular location compared to the results of the previous analysis. If the difference in voltage values between the two analyzes is quite large, then the analysis is repeated again with a larger number of elements until the difference is considered quite small. 


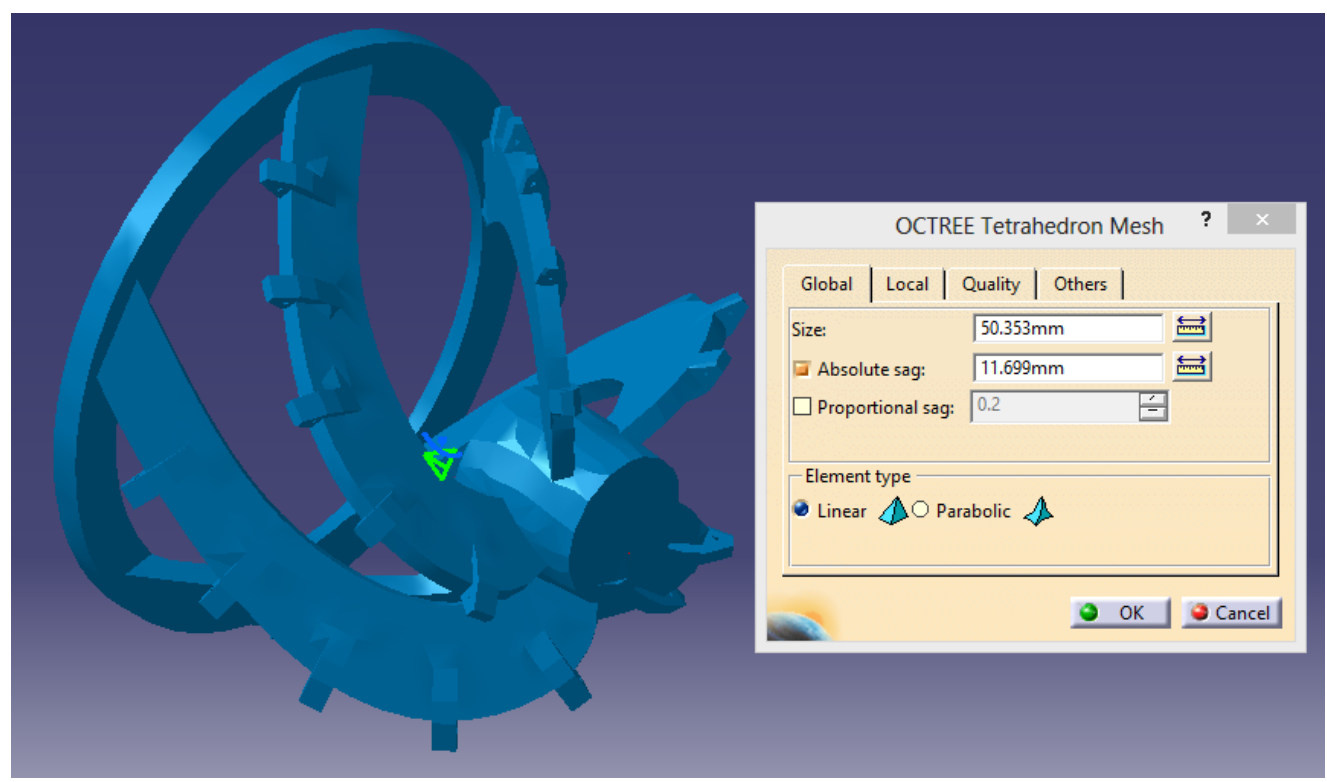

Figure 17. Setting meshing size.

In material science and engineering, the von Mises yield criteria can also be formulated in von Mises stress or equivalent tensile stress, $\sigma \mathrm{v}$, the scalar stress value can be calculated from the voltage sensor [14]. In this case, the results of convergence can be seen in the table below:

TABLE 3.

TABLE OF CONVERGENCE OF CATIA V5 GENERATE STRUCTURAL ANALYSIS SOFTWARE.

\begin{tabular}{cccccc}
\hline Type & \multicolumn{5}{c}{ Tetrahedron } \\
\hline Size & $\mathbf{3 0 m m}$ & $\mathbf{2 4 m m}$ & $\mathbf{2 0 m m}$ & $\mathbf{1 8 m m}$ & $\mathbf{1 5 m m}$ \\
\hline Nodes & $\mathbf{6 9 6 3}$ & $\mathbf{1 1 0 2 0}$ & $\mathbf{1 5 9 8 1}$ & $\mathbf{1 9 9 9 7}$ & $\mathbf{3 0 8 3 1}$ \\
\hline Element & $\mathbf{2 2 3 5 9}$ & $\mathbf{3 7 7 7 0}$ & $\mathbf{5 7 7 5 0}$ & $\mathbf{7 4 2 7 6}$ & $\mathbf{1 2 0 3 5 4}$ \\
\hline Index & Value $\mathbf{( N / \mathbf { m } ^ { 2 } )}$ & Value $\left(\mathbf{N} / \mathbf{m}^{2}\right)$ & Value $\mathbf{( N / \mathbf { m } ^ { 2 } )}$ & Value $\left(\mathbf{N} / \mathbf{m}^{2}\right)$ & Value $\left(\mathbf{N} / \mathbf{m}^{2}\right)$ \\
\hline 10 & $1.43 \mathrm{E}+08$ & $1.65 \mathrm{E}+08$ & $1.94 \mathrm{E}+08$ & $1.95 \mathrm{E}+08$ & $1.95 \mathrm{E}+08$ \\
9 & $7.98 \mathrm{E}+07$ & $8.96 \mathrm{E}+07$ & $9.81 \mathrm{E}+07$ & $1.01 \mathrm{E}+08$ & $9.56 \mathrm{E}+07$ \\
8 & $4.46 \mathrm{E}+07$ & $4.87 \mathrm{E}+07$ & $4.98 \mathrm{E}+07$ & $5.26 \mathrm{E}+07$ & $4.68 \mathrm{E}+07$ \\
7 & $2.50 \mathrm{E}+07$ & $2.65 \mathrm{E}+07$ & $2.52 \mathrm{E}+07$ & $2.73 \mathrm{E}+07$ & $2.29 \mathrm{E}+07$ \\
6 & $1.40 \mathrm{E}+07$ & $1.44 \mathrm{E}+07$ & $1.28 \mathrm{E}+07$ & $1.42 \mathrm{E}+07$ & $1.12 \mathrm{E}+07$ \\
5 & $7.80 \mathrm{E}+06$ & $7.82 \mathrm{E}+06$ & $6.49 \mathrm{E}+06$ & $7.37 \mathrm{E}+06$ & $5.50 \mathrm{E}+06$ \\
4 & $4.36 \mathrm{E}+06$ & $4.25 \mathrm{E}+06$ & $3.29 \mathrm{E}+06$ & $3.83 \mathrm{E}+06$ & $5.50 \mathrm{E}+06$ \\
3 & $2.44 \mathrm{E}+06$ & $2.31 \mathrm{E}+06$ & $1.67 \mathrm{E}+06$ & $1.99 \mathrm{E}+06$ & $1.32 \mathrm{E}+06$ \\
2 & $1.36 \mathrm{E}+06$ & $1.26 \mathrm{E}+06$ & $8.45 \mathrm{E}+05$ & $1.03 \mathrm{E}+06$ & $6.45 \mathrm{E}+05$ \\
1 & $7.62 \mathrm{E}+05$ & $6.83 \mathrm{E}+05$ & $4.29 \mathrm{E}+05$ & $5.37 \mathrm{E}+05$ & $3.16 \mathrm{E}+05$ \\
0 & $4.26 \mathrm{E}+05$ & $3.71 \mathrm{E}+05$ & $2.17 \mathrm{E}+05$ & $2.79 \mathrm{E}+05$ & $1.55 \mathrm{E}+05$ \\
\hline
\end{tabular}




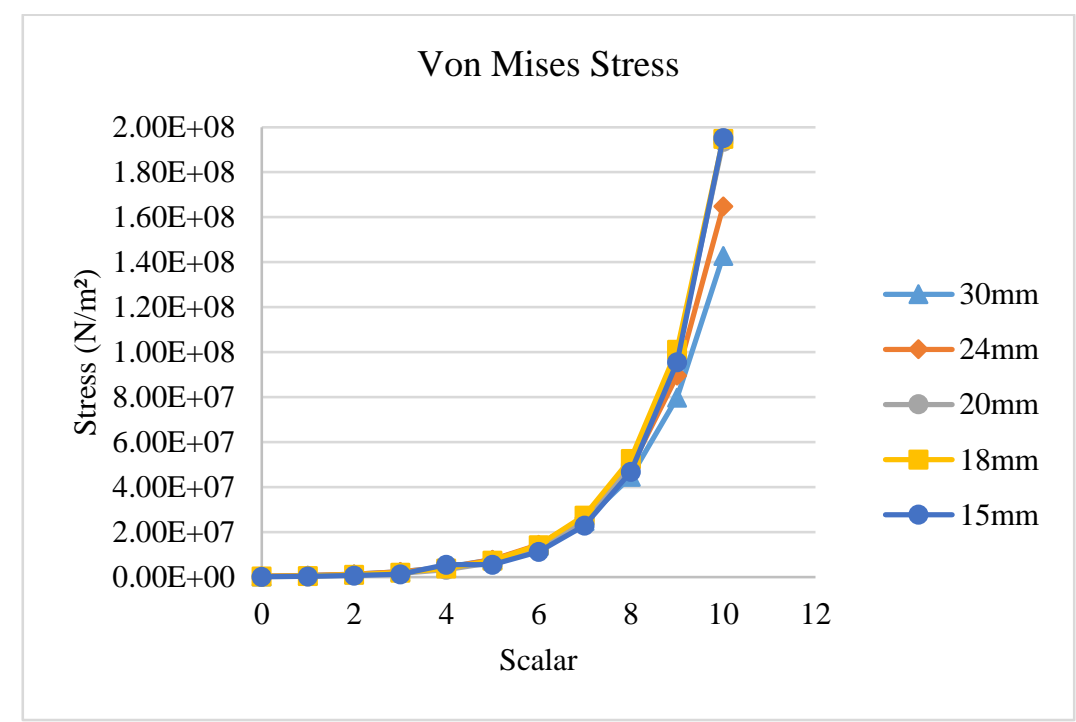

Figure 18. The results of the computational variation of meshing between Von Mises Stress and Scalar.

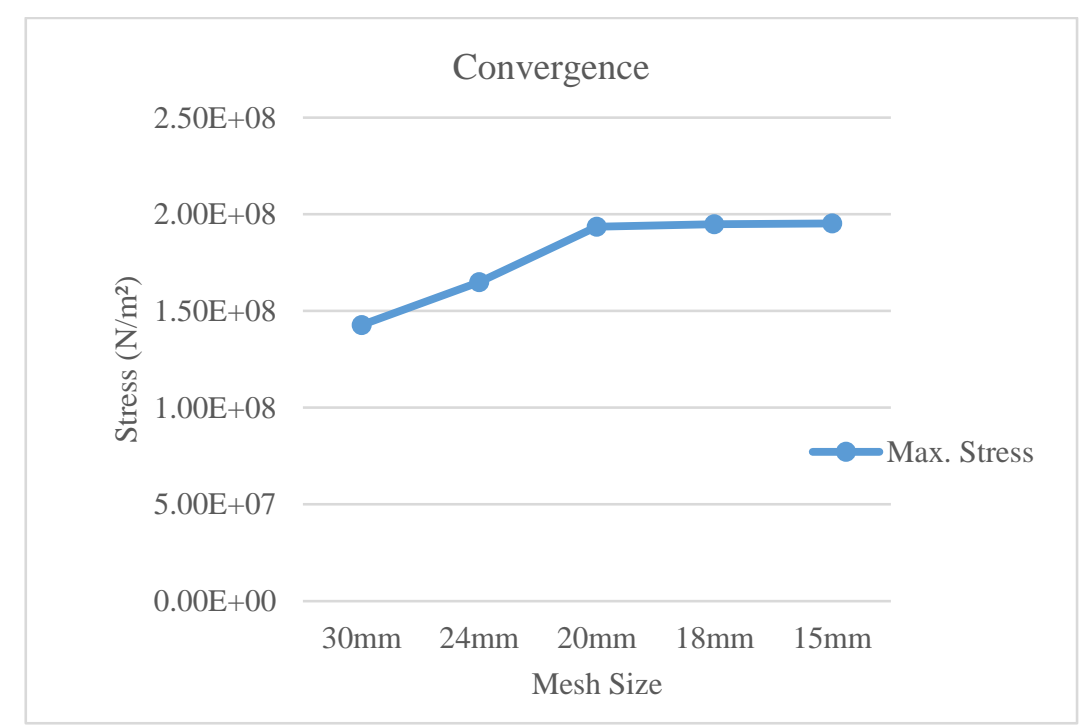

Figure 19. Convergence results in max. stress condition.

Computing above is given a force on each mounting of cutter teeth with a total of 25 points of distribution force with a value of $5950 \mathrm{~N}$ according to the maximum calculation of load design. So that the convergence of the results of computational analysis can be obtained that the type of meshing that has been used for the analysis process has been Tetrahedron with a minimum size of $18 \mathrm{~mm}$; nodes 19997; and element 74276 because in these conditions the computational process has stabilized or convergence with a maximum yield of $1.95 \mathrm{E}+08$ $\mathrm{N} / \mathrm{m}^{2}$.
C. Influences of Thickness Variations and Pitch Angles

1) Analysis of Working Condition A (WCA)

In WCA conditions constant pitch angle at an angle of $50^{\circ}$ with a force of $5950 \mathrm{~N} / \mathrm{mm}^{2}$ is varied by 4 Working Condition with changes in thickness of blade material per condition, namely: $\mathrm{WC} 1 \mathrm{~A}=25 \mathrm{~mm}$; $\mathrm{WC} 2 \mathrm{~A}=35 \mathrm{~mm}$; $\mathrm{WC} 3 \mathrm{~A}=40 \mathrm{~mm} ; \mathrm{WC} 4 \mathrm{~A}=50 \mathrm{~mm}$. Continued using $\mathrm{a}$ numerical method by using a type of Tetrahedron Mesh with a size of $17 \mathrm{~mm}$ obtained by each computational result as shown in table 4. 


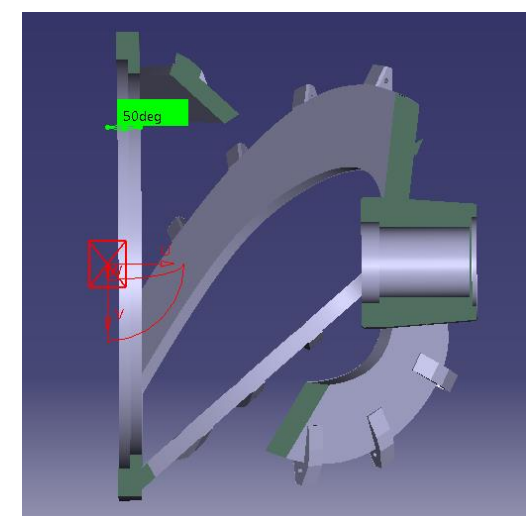

Figure 20. Section pitch conditions at $50^{\circ}$.

TABLE 4.

Distribution VALUe OF VON Mises STREsS AT THE PITCH ANGLE.

Degree
$\mathbf{5 0}^{\circ}$

\begin{tabular}{ccccc}
\hline Condition & WC1A & WC2A & WC3A & WC4A \\
\hline Thickness & $\mathbf{2 5 m m}$ & $\mathbf{3 5 m m}$ & $\mathbf{4 0 m m}$ & $\mathbf{5 0 m m}$ \\
\hline Nodes & $\mathbf{2 1 4 9 5}$ & $\mathbf{2 3 0 5 7}$ & $\mathbf{2 3 6 3 3}$ & $\mathbf{2 4 9 3 2}$ \\
\hline Element & $\mathbf{7 8 2 9 3}$ & $\mathbf{8 6 9 7 2}$ & $\mathbf{9 0 6 6 2}$ & $\mathbf{9 8 1 3 6}$ \\
\hline Index & Value $\left(\mathbf{N} / \mathbf{m}^{2}\right)$ & Value $\left(\mathbf{N} / \mathbf{m}^{2}\right)$ & Value $\left(\mathbf{N} / \mathbf{m}^{2}\right)$ & Value $\left(\mathbf{N} / \mathbf{m}^{2}\right)$ \\
\hline 10 & $2.51 \mathrm{E}+08$ & $1.97 \mathrm{E}+08$ & $1.67 \mathrm{E}+08$ & $1.28 \mathrm{E}+08$ \\
9 & $1.17 \mathrm{E}+08$ & $9.59 \mathrm{E}+07$ & $8.23 \mathrm{E}+07$ & $6.41 \mathrm{E}+07$ \\
8 & $5.43 \mathrm{E}+07$ & $4.67 \mathrm{E}+07$ & $4.06 \mathrm{E}+07$ & $3.21 \mathrm{E}+07$ \\
7 & $2.52 \mathrm{E}+07$ & $2.28 \mathrm{E}+07$ & $2.00 \mathrm{E}+07$ & $1.60 \mathrm{E}+07$ \\
6 & $1.17 \mathrm{E}+07$ & $1.11 \mathrm{E}+07$ & $9.87 \mathrm{E}+06$ & $8.02 \mathrm{E}+06$ \\
5 & $5.45 \mathrm{E}+06$ & $5.40 \mathrm{E}+06$ & $4.87 \mathrm{E}+06$ & $4.01 \mathrm{E}+06$ \\
4 & $2.53 \mathrm{E}+06$ & $2.63 \mathrm{E}+06$ & $2.40 \mathrm{E}+06$ & $2.01 \mathrm{E}+06$ \\
3 & $1.18 \mathrm{E}+06$ & $1.28 \mathrm{E}+06$ & $1.18 \mathrm{E}+06$ & $1.00 \mathrm{E}+06$ \\
2 & $5.47 \mathrm{E}+05$ & $6.23 \mathrm{E}+05$ & $5.84 \mathrm{E}+05$ & $5.01 \mathrm{E}+05$ \\
1 & $2.54 \mathrm{E}+05$ & $3.03 \mathrm{E}+05$ & $2.88 \mathrm{E}+05$ & $2.51 \mathrm{E}+05$ \\
0 & $1.18 \mathrm{E}+05$ & $1.48 \mathrm{E}+05$ & $1.42 \mathrm{E}+05$ & $1.25 \mathrm{E}+05$ \\
\hline
\end{tabular}

Figure 21. Von Mises Stress results at a $50^{\circ}$ pitch angle.

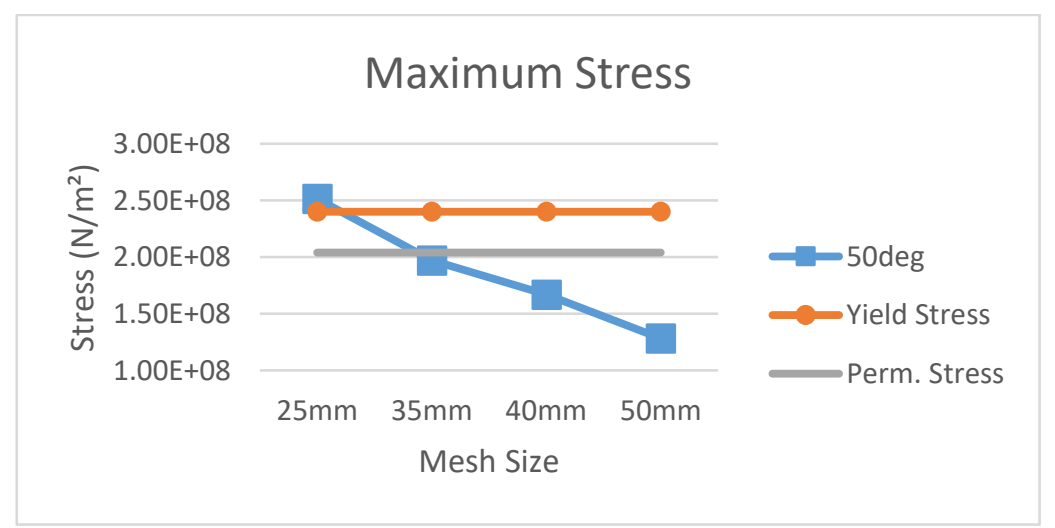

Figure 22. Maximum Von Mises Stress at $50^{\circ}$ pitch angle.

From the results of computations with a pitch $50^{\circ}$ angle, we can get that the material included in the allowable stress category is $35 \mathrm{~mm}$ thick with a maximum voltage of $1.97 \mathrm{E}+08 \mathrm{~N} / \mathrm{m}^{2}, 40 \mathrm{~mm}$ thick with a maximum voltage of $1.67 \mathrm{E}+08 \mathrm{~N} / \mathrm{m}^{2}$, and thick $50 \mathrm{~mm}$ with a maximum of $1.28 \mathrm{E}+08 \mathrm{~N} / \mathrm{m}^{2}$.

2) Analysis of Working Condition B (WCB) 
In WCB conditions a constant pitch angle at an angle of $52.5^{\circ}$ with a force of $5950 \mathrm{~N} / \mathrm{mm}^{2}$ is varied by 4 Working Condition with changes in thickness of blade material per condition, namely $\mathrm{WC} 1 \mathrm{~B}=25 \mathrm{~mm}$; WC2B $=35 \mathrm{~mm} ; \mathrm{WC} 3 \mathrm{~B}=40 \mathrm{~mm} ; \mathrm{WC} 4 \mathrm{~B}=50 \mathrm{~mm}$.

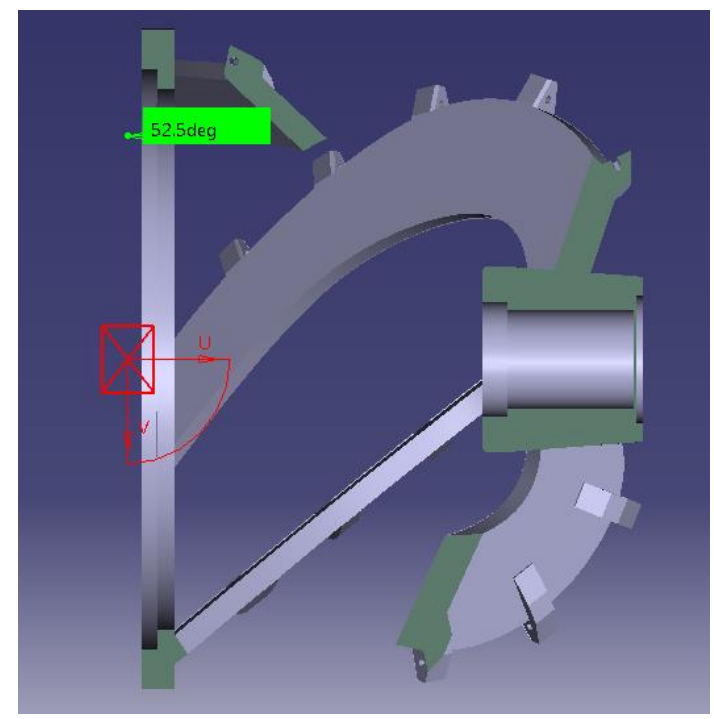

Figure 23. Section pitch conditions at $52.5^{\circ}$.

TABLE 5.

Distribution VALUe OF VON Mises STREsS AT THE PITCH ANGLE $52.5^{\circ}$.

\begin{tabular}{|c|c|c|c|c|}
\hline Degree & \multicolumn{4}{|c|}{$52.5^{\circ}$} \\
\hline Condition & WC1B & WC2B & WC3B & WC4B \\
\hline Thickness & $25 \mathrm{~mm}$ & $35 \mathrm{~mm}$ & $40 \mathrm{~mm}$ & $50 \mathrm{~mm}$ \\
\hline Nodes & 21905 & 23642 & 23227 & 24780 \\
\hline Element & 80229 & 89084 & 89120 & 97272 \\
\hline Index & Value $\left(\mathbf{N} / \mathbf{m}^{2}\right)$ & Value $\left(\mathbf{N} / \mathbf{m}^{2}\right)$ & Value $\left(\mathbf{N} / \mathbf{m}^{2}\right)$ & Value $\left(\mathbf{N} / \mathbf{m}^{2}\right)$ \\
\hline 10 & $2.66 \mathrm{E}+08$ & $1.97 \mathrm{E}+08$ & $1.77 \mathrm{E}+08$ & $1.43 \mathrm{E}+08$ \\
\hline 9 & $1.33 \mathrm{E}+08$ & $1.01 \mathrm{E}+08$ & $9.21 \mathrm{E}+07$ & $7.44 \mathrm{E}+07$ \\
\hline 8 & $6.62 \mathrm{E}+07$ & $5.20 \mathrm{E}+07$ & $4.81 \mathrm{E}+07$ & $3.88 \mathrm{E}+07$ \\
\hline 7 & $3.30 \mathrm{E}+07$ & $2.67 \mathrm{E}+07$ & $2.51 \mathrm{E}+07$ & $2.02 \mathrm{E}+07$ \\
\hline 6 & $1.65 \mathrm{E}+07$ & $1.37 \mathrm{E}+07$ & $1.31 \mathrm{E}+07$ & $1.06 \mathrm{E}+07$ \\
\hline 5 & $8.23 \mathrm{E}+06$ & $7.04 \mathrm{E}+06$ & $6.82 \mathrm{E}+06$ & $5.51 \mathrm{E}+06$ \\
\hline 4 & $4.11 \mathrm{E}+06$ & $3.61 \mathrm{E}+06$ & $3.56 \mathrm{E}+06$ & $2.87 \mathrm{E}+06$ \\
\hline 3 & $2.05 \mathrm{E}+06$ & $1.86 \mathrm{E}+06$ & $1.85 \mathrm{E}+06$ & $1.50 \mathrm{E}+06$ \\
\hline 2 & $1.02 \mathrm{E}+06$ & $9.53 \mathrm{E}+05$ & $9.67 \mathrm{E}+05$ & $7.82 \mathrm{E}+05$ \\
\hline 1 & $5.11 \mathrm{E}+05$ & $4.89 \mathrm{E}+05$ & $5.04 \mathrm{E}+05$ & $4.08 \mathrm{E}+05$ \\
\hline 0 & $2.55 \mathrm{E}+05$ & $2.51 \mathrm{E}+05$ & $2.63 \mathrm{E}+05$ & $2.13 \mathrm{E}+05$ \\
\hline
\end{tabular}




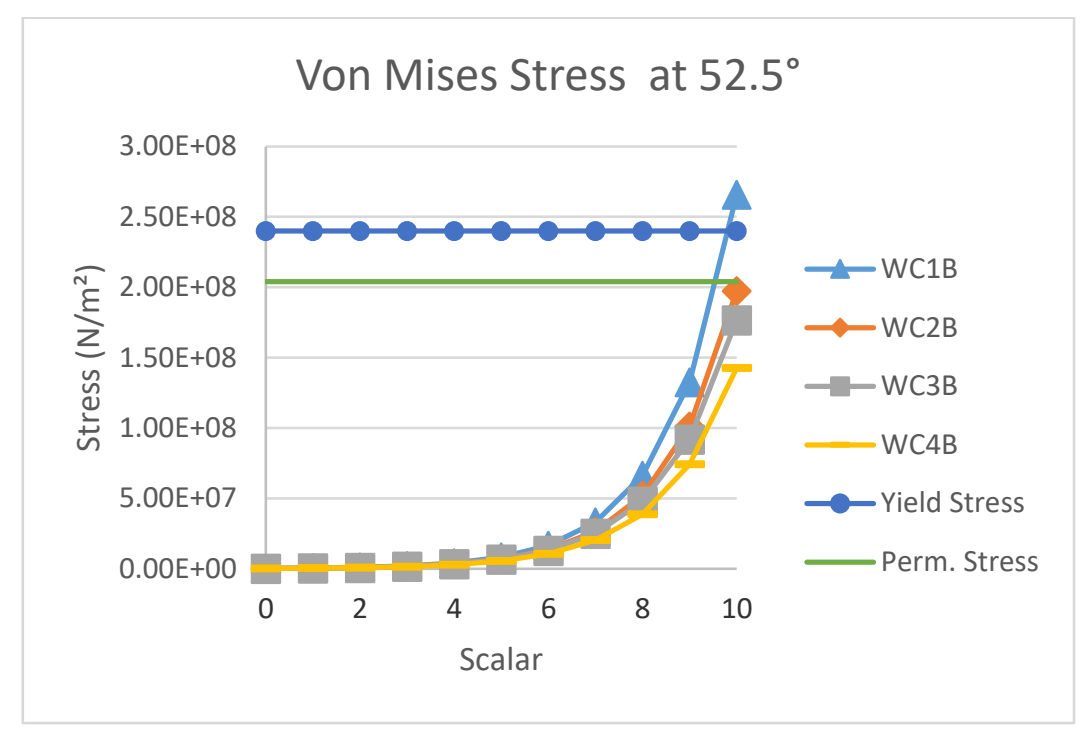

Figure 24. Von Mises Stress results at $52.5^{\circ}$ pitch angle.

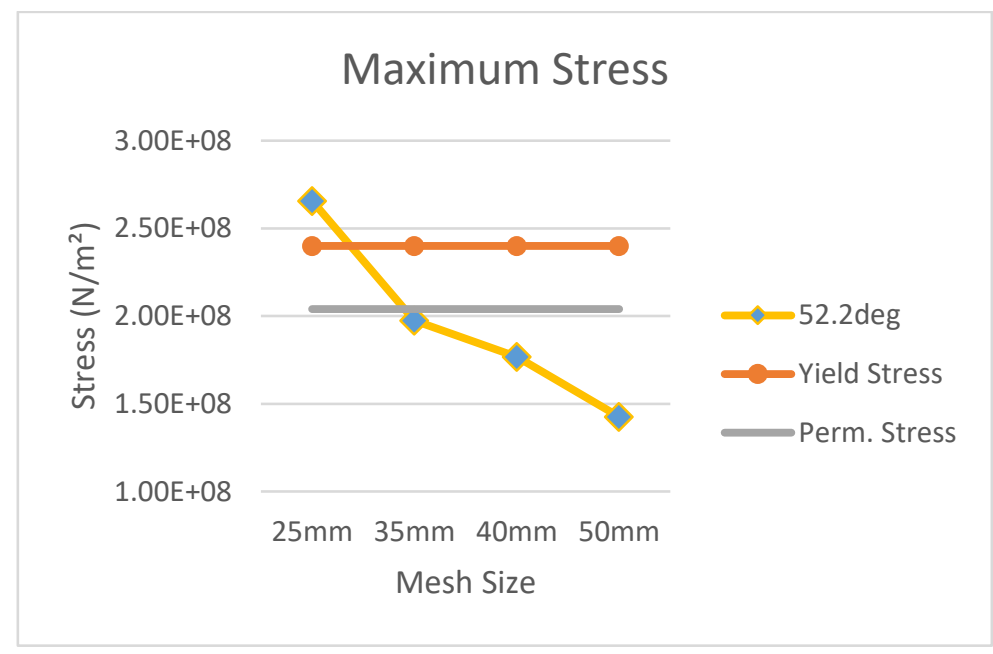

Figure 25. Maximum Von Mises Stress at $52.5^{\circ}$ pitch angle.

From the computation results with a pitch of $52.5^{\circ}$ we can find that the material included in the permissible stress category is $35 \mathrm{~mm}$ thick with maximum stress $1.97 \mathrm{E}+08 \mathrm{~N} / \mathrm{m}^{2}, 40 \mathrm{~mm}$ thick with maximum stress $1.77 \mathrm{E}+08 \mathrm{~N} / \mathrm{m}^{2}$ and thick $50 \mathrm{~mm}$ with a maximum of $1.43 \mathrm{E}+08 \mathrm{~N} / \mathrm{m}^{2}$.
3) Analysis of Working Condition C (WCC)

In WCC conditions the condition of a constant pitch angle at an angle of $55^{\circ}$ with a force of $5950 \mathrm{~N} / \mathrm{mm}^{2}$ is varied by 4 Working Condition with changes in thickness of blade material per condition, namely: $\mathrm{WC} 1 \mathrm{C}=25 \mathrm{~mm} ; \mathrm{WC} 2 \mathrm{C}=35 \mathrm{~mm} ; \mathrm{WC} 3 \mathrm{C}=40 \mathrm{~mm}$; $\mathrm{WC} 4 \mathrm{C}=50 \mathrm{~mm}$.

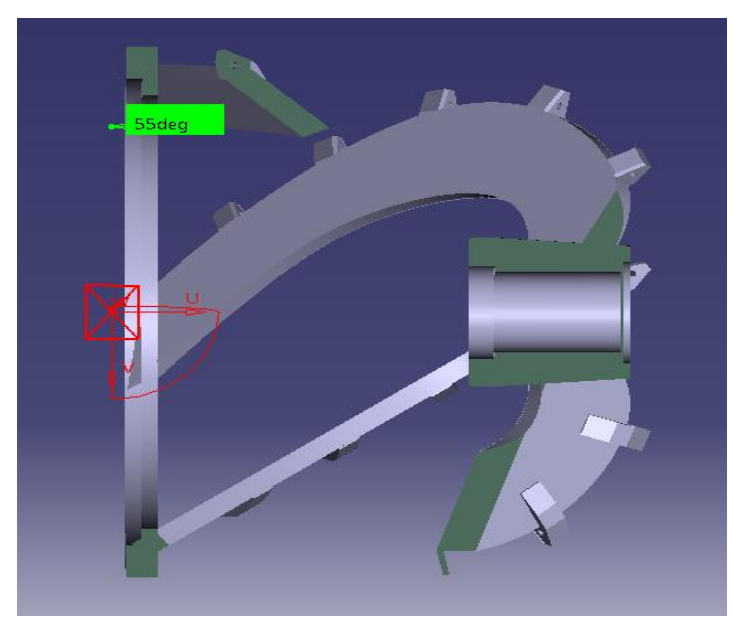

Figure 26. Section pitch conditions at $55^{\circ}$. 
Continued using a numerical method by using a type $\quad$ Each computing result as shown in table 6. of Tetrahedron Mesh with a size of $17 \mathrm{~mm}$ obtained by

TABLE 6.

VALUE DISTRIBUTION OF VON MISES STRESS AT $55^{\circ}$ PITCH ANGLE.

\begin{tabular}{|c|c|c|c|c|}
\hline Degree & \multicolumn{4}{|c|}{$\mathbf{5 5}^{\circ}$} \\
\hline Condition & WC1C & WC2C & WC3C & WC4C \\
\hline Thickness & $25 \mathrm{~mm}$ & $35 \mathrm{~mm}$ & $40 \mathrm{~mm}$ & $50 \mathrm{~mm}$ \\
\hline Nodes & 21916 & 22456 & 23302 & 25497 \\
\hline Element & 80047 & 84570 & 89116 & 100788 \\
\hline Index & Value $\left(\mathbf{N} / \mathbf{m}^{2}\right)$ & Value $\left(\mathbf{N} / \mathbf{m}^{2}\right)$ & Value $\left(\mathbf{N} / \mathbf{m}^{2}\right)$ & Value $\left(\mathrm{N} / \mathrm{m}^{2}\right)$ \\
\hline 10 & $2.88 \mathrm{E}+08$ & $2.01 \mathrm{E}+08$ & $1.84 \mathrm{E}+08$ & $1.36 \mathrm{E}+08$ \\
\hline 9 & $1.34 \mathrm{E}+08$ & $9.96 \mathrm{E}+07$ & $9.13 \mathrm{E}+07$ & $6.93 \mathrm{E}+07$ \\
\hline 8 & $6.27 \mathrm{E}+07$ & $4.94 \mathrm{E}+07$ & $4.54 \mathrm{E}+07$ & $3.53 \mathrm{E}+07$ \\
\hline 7 & $2.93 \mathrm{E}+07$ & $2.45 \mathrm{E}+07$ & $2.26 \mathrm{E}+07$ & $1.80 \mathrm{E}+07$ \\
\hline 6 & $1.37 \mathrm{E}+07$ & $1.21 \mathrm{E}+07$ & $1.12 \mathrm{E}+07$ & $9.14 \mathrm{E}+06$ \\
\hline 5 & $6.37 \mathrm{E}+06$ & $6.01 \mathrm{E}+06$ & $5.57 \mathrm{E}+06$ & $4.65 \mathrm{E}+06$ \\
\hline 4 & $2.97 \mathrm{E}+06$ & $2.98 \mathrm{E}+06$ & $2.77 \mathrm{E}+06$ & $2.37 \mathrm{E}+06$ \\
\hline 3 & $1.39 \mathrm{E}+06$ & $1.48 \mathrm{E}+06$ & $1.37 \mathrm{E}+06$ & $1.20 \mathrm{E}+06$ \\
\hline 2 & $6.48 \mathrm{E}+05$ & $7.31 \mathrm{E}+05$ & $6.83 \mathrm{E}+05$ & $6.13 \mathrm{E}+05$ \\
\hline 1 & $3.02 \mathrm{E}+05$ & $3.62 \mathrm{E}+05$ & $3.39 \mathrm{E}+05$ & $3.12 \mathrm{E}+05$ \\
\hline 0 & $1.41 \mathrm{E}+05$ & $1.80 \mathrm{E}+05$ & $1.69 \mathrm{E}+05$ & $1.59 \mathrm{E}+05$ \\
\hline
\end{tabular}

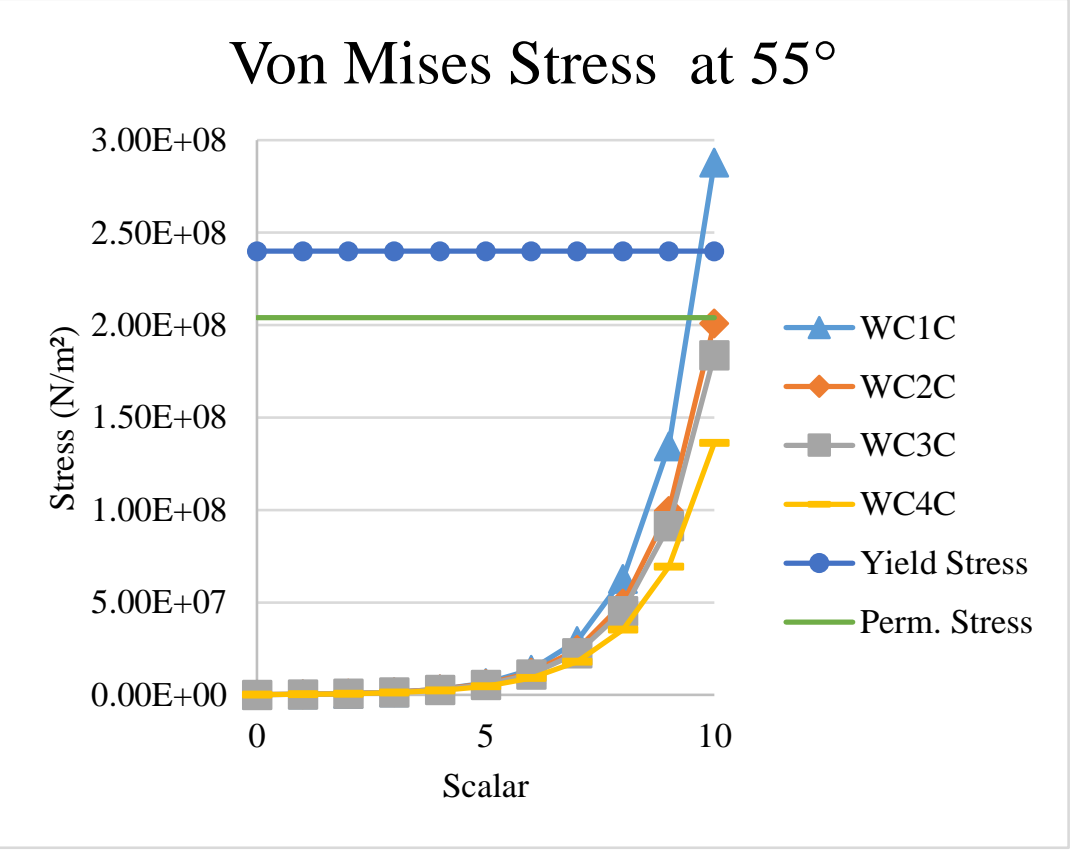

Figure 27. Von Mises Stress result at $55^{\circ}$ pitch angle. 


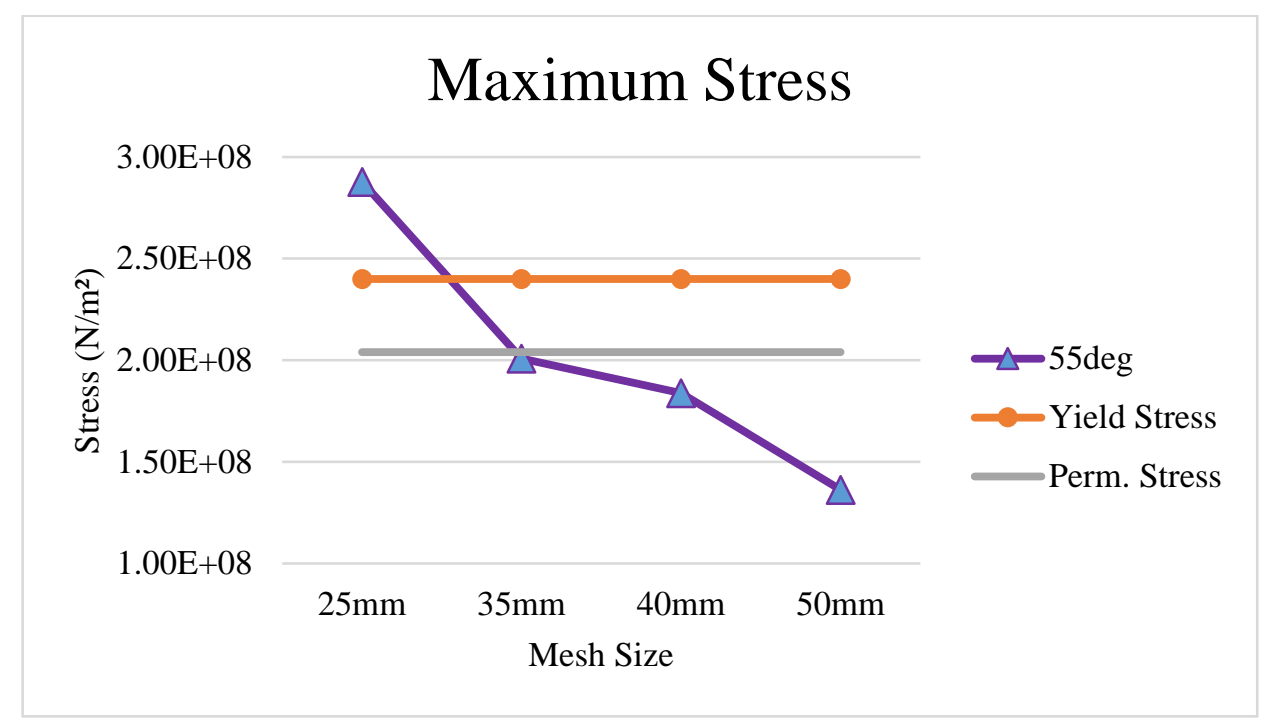

Figure 28. Maximum Von Mises Stress at $55^{\circ}$ pitch angle.

From the results of computations with a pitch $55^{\circ}$ angle, we can obtain that the material included in the allowable stress category is $35 \mathrm{~mm}$ thick with a voltage of $2.01 \mathrm{E}+08 \mathrm{~N} / \mathrm{m}^{2}, 40 \mathrm{~mm}$ thick with a maximum voltage of $1.84 \mathrm{E}+08 \mathrm{~N} / \mathrm{m}^{2}$, and thick $50 \mathrm{~mm}$ with a maximum of $1.36 \mathrm{E}+08 \mathrm{~N} / \mathrm{m}^{2}$.
4) Design Voltage Analysis Study

Computing varied from several working conditions above shows the difference in results seen from the maximum stress obtained. In order to simplify the overall analysis, it is presented in the graph below:

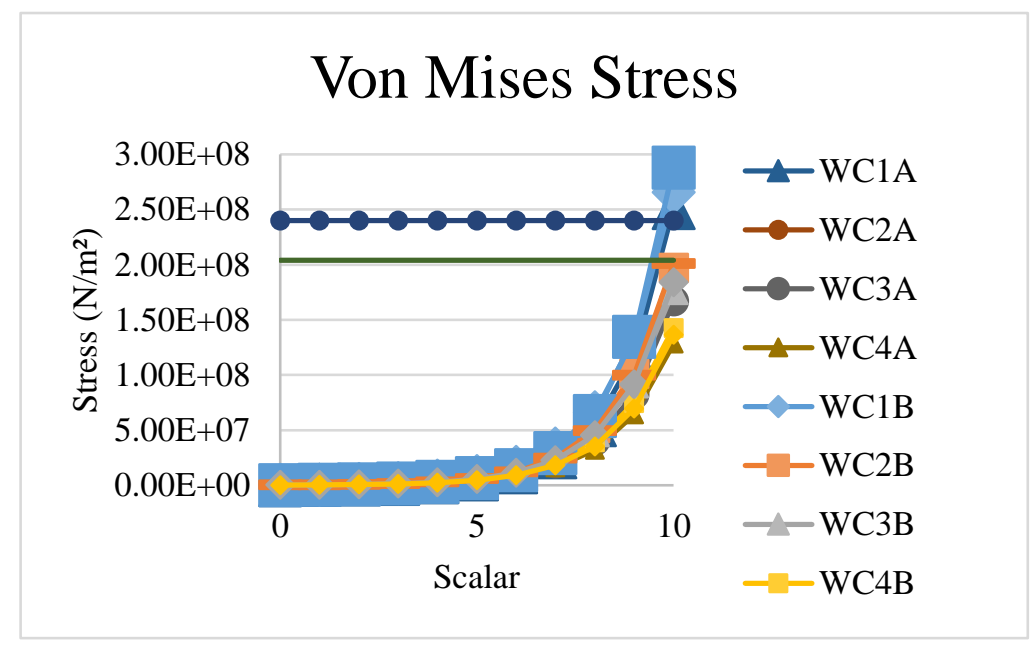

Figure 29. Von Mises Stress results.

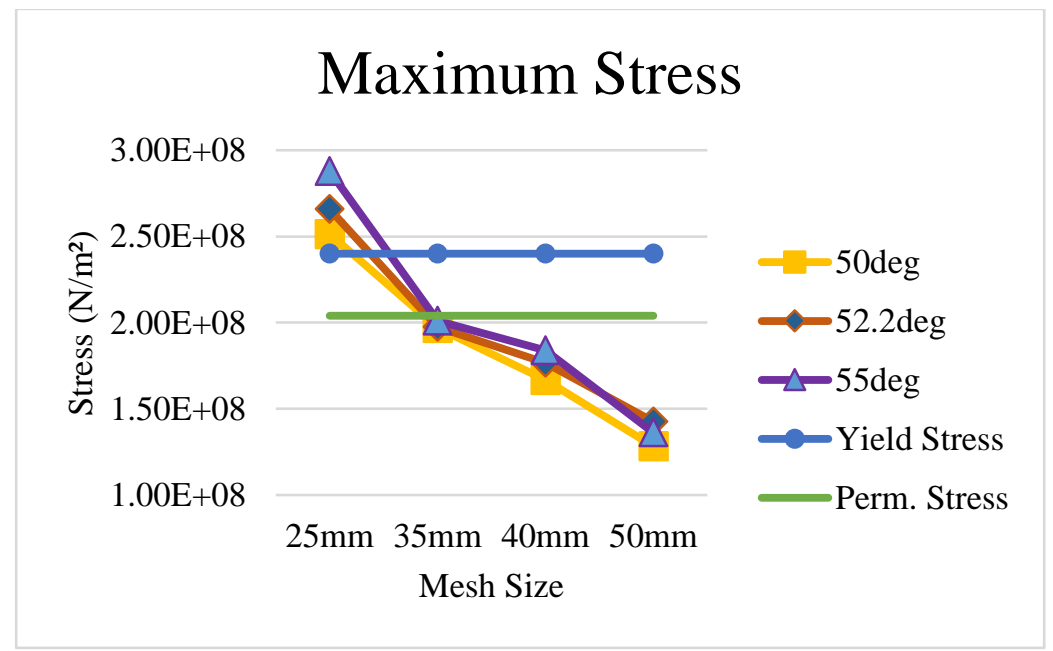

Figure 30. Maximum Von Mises Stress 
Looking at the graph above, what is not included in the allowable stress category is the angle of $50^{\circ} 25 \mathrm{~mm}$ thick with a maximum voltage of $2.51 \mathrm{E}+08 \mathrm{~N} / \mathrm{m}^{2}$, angle $52.5^{\circ}$ $25 \mathrm{~mm}$ thick with a maximum voltage of $2.66 \mathrm{E}+08 \mathrm{~N} / \mathrm{m}^{2}$, angle $55^{\circ} 25 \mathrm{~mm}$ thick with a maximum voltage of $2.88 \mathrm{E}+08 \mathrm{~N} / \mathrm{m}^{2}$.

\section{CONCLUSION}

From the results of calculations and computations that have been done, the writer can draw conclusions:

Design of Cutter Head brief as below:

a. The ability of the Cutter Head is designed to operate within $8 \mathrm{~m}$ with the ability to dredging on Soft soil material with estimated material found namely Salt, Coarse-grained, Fossiliferous limestones, Altered Igneous Rock, Claystones, and Coal. The medium with the estimated material found is (Marlstones, Limestones, Marble, Shales, Phyllites, Highly Micaceous Schists, Altered Intrusive Igneous Rocks, and altered Metamorphic Rocks). Material stress strength is estimated to work at a relatively soft density of $<100 \mathrm{Mpa}$ and for Medium around 100 Mpa - 170 Mpa.

b. The Blade Cutter design of Figure design has a slope angle of $52.5^{\circ}$ with a cross-section of 35 $\mathrm{mm}$ thickness, the width of $126 \mathrm{~mm}$, has maximum stress $197 \mathrm{~N} / \mathrm{mm}^{2}$ and that value below the permissible stress $204 \mathrm{~N} / \mathrm{mm}^{2}$.

c. With a crown, there are 5 Blades Cutter with 5 mounting on each blade, having a $1,000 \mathrm{~mm}$ diameter geometry with a minimum power circular rotor needed is $9.34 \mathrm{~kW}$.

The stress of the cutter blade is influenced by the thickness and angle of the pitch.

a. The cutter blade design is within 5 cross-sections, 5 force distributions in each blade, the given force is $5,950 \mathrm{~N}$, and the area of each blade is 152.97 $\mathrm{mm}^{2}$.

b. The design of the cutter blade is not intended to break hard rock because to break hard rock requires a force of approximately 3 tons or the equivalent of 29,430 N [15].

c. Based on the computational results, if the material has a larger and thicker angle then the smaller the resulting stress is also greater, so to get an acceptable design that the stress design value does not exceed the allowable stress. d. The cutter teeth are planned to be used in $8 \mathrm{~m}$ with a prediction of relatively Soft soil material $<100$ Mpa and for Medium around $100 \mathrm{Mpa}-170 \mathrm{Mpa}$. The cutter teeth material to be used is the $\mathrm{S} 2$ series Stell Alloy which has a hardness value of $440-520 \mathrm{HB}$ and a yield of $1500 \mathrm{~N} / \mathrm{mm}^{2}$ which is suitable to guarantee the toughness of cutter teeth because the minimum material cutter voltage must be at 40 HRC (Rockwell C Hardness) or 373 HB (Brinell Hardness) or 388 HV (Vickers Hardness) or minimum cutter material voltage of $1265 \mathrm{~N} / \mathrm{mm}^{2}$ [9].

\section{ACKNOWLEDGMENT}

We thank PT. Orela Shipyard for the Catia Software and Marine Manufacturing Design (MMD) Laboratory of Marine Engineering Department ITS for the support of this research.

\section{REFERENCES}

[1] N. Anggraini, "Ujung Pangkah Shoreline Change Analysis Using Edge Detection Method and Normalized Difference Water Index," pp. 65-78, 2017.

[2] S. Sulma, "Terhadap Kenaikan Muka Air Laut ( Studi Kasus : Surabaya Dan Daerah Sekitarnya )," 2012.

[3] S. R. Firdaus, S. Saputro, and A. Satriadi, "Studi Pengerukan Alur Pelayaran Pelabuhan Tanjung Emas Semarang," J-Ose Undip, vol. 2, no. 3, pp. 274-279, 2013.

[4] W. J. Vlasblom, Introduction to Dredging Equipment. 2003.

[5] A. Kagie, "Development of a numerical model for Cutter Suction Dredgers," 2018.

[6] A. Tasevski and C. Hedlund, "Design of Bucket Teeth," 2016

[7] J. Cook and H. Bock, "Geomechanical Investigation Of Coral Reef Structure Report Submitted To Great Barrier Reef Marine Park Authority," Townsville.

[8] H. J. Hignett, "The Current State of the Art of Rock Cutting and Dredging Tls Army E Us Army Corps of Engineers US Army Corps of Engineers," 1984.

[9] S. H. Suryo, "Parameter Optimization of Heat Treatment on AISI 4140 Material Hardness Value for Bucket Teeth Application Using Taguchi Method,” J. Eng. Appl. Sci., 2018.

[10] ASTMA681, Standard Specification for Tool Steels Alloy 1. 2010.

[11] S. Hirako, "Study on Layout and Construction Concept of Dms (Modular Simplified Medium Small Reactor)," 2008.

[12] D. Mikulic, "Design of demining machines," 2013.

[13] S. Loewenthal, "Design of Power-transmitting Shafts," Natl Aeronaut, 1984

[14] B. A. B. Iii and A. T. V. O. N. Mises, "Analisa Tegangan Von Mises."

[15] A. J. Joshi and D. J. P. Modak, "Design And Development Of A Small Capacity Stone Crusher Mechanism," Indian J Appl, vol. 3, no. 2, pp. 106-109, 2011 